\title{
Optimization of bio-succinic fermentation process from crude glycerol by Actinobacillus succinogenes
}

\author{
Suwimon Kanchanasuta ${ }^{1,2^{\dagger}}$, Verawat Champreda ${ }^{3}$, Nipon Pisutpaisal ${ }^{4}$, Chatchawal Singhakant ${ }^{1,2}$ \\ ${ }^{1}$ Mahidol University, Faculty of Public Health, Department of Environmental Health Sciences, 420/1 Rajvithi RD., Ratchathewi District, Bangkok \\ 10400 Thailand \\ ${ }^{2}$ Center of Excellence on Environmental Health and Toxicology, Bangkok, Thailand \\ ${ }^{3}$ Biorefinery and Bioproduct Research Group, National Center for Genetic Engineering and Biotechnology, 113 Thailand Science Park, Paholyothin \\ RD., Khlong Luang District, Pathumthani 12120 Thailand \\ ${ }^{4}$ King Mongkut's University of Technology North Bangkok, Faculty of Applied Science, Department of Agro-industrial, Food and Environmental \\ Technology, 1518 Pracharat1 RD., Bangsue District, Bangkok 10800 Thailand
}

\begin{abstract}
Bio-succinic acid is a commodity chemical with potent application in bioplastic and food industries which can be produced from renewable resources. In this study, bioprocess for production of bio-succinic from glycerol by Actinobacillus succinogenes was studied. The maximum succinic acid concentration in small-scale serum bottle experiments was 6.8 and $6.5 \mathrm{~g} / \mathrm{L}$ using pure and crude glycerol, respectively, with supplemented $\mathrm{MgCO}_{3}$. The ratio of acetic acid to succinic acid (AA/SA) implied the increased carbon flux to the $\mathrm{C}_{4}$ pathway using crude glycerol supplemented with $\mathrm{MgCO}_{3}$ compared to that with $\mathrm{CaCO}_{3}$. The carbonate salts tended to induce $\mathrm{C}_{3}$ metabolic pathway in fermentation using pure glycerol which was in accordance with the ratio of acetic acid to glycerol (AA/GL). The highest succinic acid concentration of $17.9 \mathrm{~g} / \mathrm{L}$ from crude glycerol was achieved from batch fermentation in a lab-scale fermenter with the maximum glycerol utilization of $99.9 \%$ which were higher than those obtained from fed- batch and semi-continuous processes. Acetic acid tended to increase throughout the fermentation process in fed-batch and semi-continuous operations, which resulted in the lower product yield and substrate utilization efficiency. The time for initial purging of $\mathrm{CO}_{2}$ showed effects on succinic acid production and internal metabolic pathways. This work provided a basis for process development on bio-succinic acid production from crude glycerol in industry.
\end{abstract}

Keywords: Actinobacillus Succinogenes, bio-succinic acid, carbonate salts, crude glycerol, fed-batch, semi-continuous

\section{Introduction}

Biodiesel is an interesting alternative fuel to replace fossil fuels because of its competitive energy properties and potential on production from agricultural products such as palm oil. According to the Alternative Energy Development Plan (AEDP) 2015-2036, reported that the Thai government plans to promote biodiesel production up to 14 million liters daily by 2036 [1]. In the biodiesel production process, $10 \mathrm{~kg}$ of crude glycerol (CG) with approximately $30-60 \%$ purity is generated from $100 \mathrm{~kg}$ of biodiesel produced. CG can be further purified to high purity glycerol with more than 90\% purity for application in pharmaceutical, food and cosmetics industries. The rest of CG is discarded in landfills which can lead to environmental impacts. Some small biodiesel producers also burn excess CG as the way for its disposal which results in air pollution. Alternatively, CG can be used as a raw material for conversion to various products such as ethanol, animal feed, biogas, 1, 3-propanediol, polyunsaturated fatty acids, lipids, polyhydroxyalkanoates (PHA) and succinic acid through different biological processes [2-6].

Bio-succinic acid is a commodity chemical, which can be produced from renewable raw materials by environmentally-friendly microbial processes $[5,6]$. Currently, most succinic acid is produced from maleic anhydride (MAN) by catalytic processes [7] which are energy intensive and generates chemical wastes. Succinic acid can be used for many applications, such as lubricant, solvent,
This is an Open Access article distributed under the terms of the Creative Commons Attribution Non-Commercial License (http://creativecommons.org/licenses/by-nc/3.0/) which permits unrestricted non-commercial use, distribution, and reproduction in any medium, provided the original work is properly cited.

Copyright (C) 2021 Korean Society of Environmental Engineers
Received March 11, 2020 Accepted August 07, 2020

${ }^{\dagger}$ Corresponding author

Email: suwimon.kan@mahidol.ac.th

Tel: +66-2354-8525 Fax: +66-2354-8525

ORCID: 0000-0002-6824-6133 
and as ingredients in cosmetic and pharmaceutical products or can be converted to 1,-4 butanediol (BDO) and polybutyrate succinate (PBS) [8, 9]. Development of an efficient fermentation process for its production from inexpensive feedstock is thus of interest for industrial application.

Production of bio-succinic acid from diverse substrates has been reported using different microorganisms and mode of operations in fermentation. These microbes include Mannheimia succinoproducens, Yarrowia lipolytica and Actinobacillus succinogenes which resulted in the final succinic acid titer in the range of 9.4-151.4 $\mathrm{g} / \mathrm{L}$ with the product yield ranging from 0.4-1.5 g/g [10-18]. Among various microbes, $A$. succinogenes is a potent succinic acid producer with advantages on its capability to produce high concentrations of succinic acid and high tolerance to acid produced during fermentation [19] However, studies on utilization of CG by $A$. succinogenes for succinic acid production have been limited to only very few reports [19] while its relevant metabolic pathways are not well characterized. In this work, we aimed to study the application of this bacterium for bio-succinic acid production from CG with the focuses on effects of carbonate salts and different operation modes including batch, fed batch and semi-continuous fermentation. The effects of $\mathrm{CO}_{2}$ purging to the fermentation system were studied. The internal metabolic pathway was investigated based on the metabolites produced during fermentation to evaluate the efficiency on bio-succinic production. The work provides basis for valorization of CG to succinic acid for further development to industrial implementation.

\section{Material and Methods}

\subsection{Materials}

Crude glycerol (CG) and pure glycerol (PG) were obtained from Patum Vegetable Oil Co., Ltd, Pathum Thani, Thailand. Characteristics of CG and PG are summarized in Table 1.

\subsection{Inoculum Preparation}

A. succinogenes (ATCC $55618^{\mathrm{TM}}$ ) was purchased from ATCC $^{\circledR}$ culture collection (www.atcc.org). Inoculum was re-cultivated from $-20^{\circ} \mathrm{C}$ glycerol stock in $100 \mathrm{~mL}$ serum flasks, containing $20 \mathrm{~mL}$ of trypticase soy broth (TSB). After that, the serum bottle was purged with $\mathrm{CO}_{2}$ (flow rate $1 \mathrm{~L} / \mathrm{min}$ for $1 \mathrm{~min}$ ) to create anaerobic conditions. Next, the serum bottle was incubated in a shaking incubator at $37^{\circ} \mathrm{C}$ with rotary shaking at $200 \mathrm{rpm}$ for $24 \mathrm{~h}$. After that, $10 \mathrm{~mL}$ of culture was added to the serum bottle containing $50 \mathrm{~mL}$ of TSB $(20 \% \mathrm{v} / \mathrm{v})$ and then purged with $\mathrm{CO}_{2}$ (flow rate $1 \mathrm{~L} / \mathrm{min}$ for $1 \mathrm{~min})$. Finally, all serum bottles were incubated at $37^{\circ} \mathrm{C}$ with rotary shaking at $200 \mathrm{rpm}$ for $12 \mathrm{~h}$ before use.

\subsection{Effects of $P G$ and $C G$ and Carbonate Salts on Succinic Acid Production}

The effects of using PG and CG with supplementation of different carbonate salts $\left(\mathrm{MgCO}_{3}\right.$ and $\left.\mathrm{CaCO}_{3}\right)$ were studied in $100 \mathrm{ml}$ serum bottles with a working volume of $50 \mathrm{~mL}$. Each liter of the medium contained (in g/L): 5.0 g yeast extract, $8.4 \mathrm{~g} \mathrm{NaHCO}_{3}, 8.5 \mathrm{~g}$ $\mathrm{NaH}_{2} \mathrm{PO}_{4} \cdot \mathrm{H}_{2} \mathrm{O}, 15.5$ g K $\mathrm{HPO}_{4}, 1.0$ g $\left(\mathrm{NH}_{4}\right)_{2} \mathrm{SO}_{4}, 0.2$ g MgCl $2.6 \mathrm{H}_{2} \mathrm{O}$, and $0.2 \mathrm{~g} \mathrm{CaCl}_{2}$ [5]. The initial concentration of glycerol in all conditions was fixed at $10 \mathrm{~g} / \mathrm{L}$. All conditions were inoculated with $20 \% \mathrm{v} / \mathrm{v}$ of inoculum and then purged with $\mathrm{CO}_{2}$ at a flow rate of $1 \mathrm{~L} / \mathrm{min}$ for $1 \mathrm{~min}$. After that, the serum bottles were incubated in a shaking incubator at $37^{\circ} \mathrm{C}, 200 \mathrm{rpm}$. PG or CG were used as the main carbon source in bio-succinic acid fermentation. The concentration of carbonate salts $\left(\mathrm{MgCO}_{3}\right.$ and $\left.\mathrm{CaCO}_{3}\right)$ was varied at 20,40 and $60 \mathrm{mg} / \mathrm{L}$ to evaluate the effects of metabolic pathway on bio-succinic acid fermentation. All experimental data were performed in duplicate from two independent experiments. Mean values with standard deviation were reported.

\subsection{Succinic acid Production in Continuous Stirred-Tank Reactor (CSTR)}

The prepared free cells after re-cultivation were used for fermentation in a 1-L CSTR with a working volume of $720 \mathrm{~mL}$. Each liter of medium contained (in g/L): 5.0 g yeast extract, $8.4 \mathrm{~g} \mathrm{NaHCO}_{3}$, $8.5 \mathrm{~g} \mathrm{NaH}_{2} \mathrm{PO}_{4} \cdot \mathrm{H}_{2} \mathrm{O}, 15.5 \mathrm{~g} \mathrm{~K}_{2} \mathrm{HPO}_{4}, 1.0 \mathrm{~g}\left(\mathrm{NH}_{4}\right) 2 \mathrm{SO}_{4}, 0.2$ g MgCl $2.6 \mathrm{H}_{2} \mathrm{O}$ and $0.2 \mathrm{~g} \mathrm{CaCl}_{2}$ [5]. $120 \mathrm{~mL}$ of inoculum $(20 \% \mathrm{v} / \mathrm{v})$ was added to the CSTR containing $600 \mathrm{~mL}$ of the medium supplemented with 1\%w/v CG and $20 \mathrm{~g} / \mathrm{L} \mathrm{MgCO}_{3}$. Before fermentation, the systems were initially purged with gaseous $\mathrm{CO}_{2}$ at a flow rate $1 \mathrm{~L} / \mathrm{min}$ for $1 \mathrm{~min}$ to provide anaerobic conditions. All experiments in the CSTR were controlled at $37^{\circ} \mathrm{C}$ with a mixing speed at $150 \mathrm{rpm}$. The experiments were designed to study the effect of operation modes including batch, fed-batch and semi-continuous operation. The amount of dissolved $\mathrm{CO}_{2}$ was studied by varying the period of $\mathrm{CO}_{2}$ purging for 1,3 and 5 min to compare the efficiency of succinic acid production and the internal metabolic pathways by $A$. succinogenes. All operation modes were run in duplicate with two independent experiments. Mean values with standard deviation were reported.

\subsubsection{Batch fermentation}

This mode was started by mixing $120 \mathrm{~mL}$ of the initial inoculum $(20 \% \mathrm{v} / \mathrm{v})$ with $600 \mathrm{~mL}$ of the medium supplemented with $1 \% \mathrm{w} / \mathrm{v}$ of $\mathrm{CG}$ and $20 \mathrm{~g} / \mathrm{L} \mathrm{MgCO}_{3}$. The mixture was fermented for $7 \mathrm{~d}$ $(168 \mathrm{~h})$ under the fixed condition at $37^{\circ} \mathrm{C}$ with mixing at $150 \mathrm{rpm}$.

\subsubsection{Fed-batch fermentation}

This mode was started by mixing $120 \mathrm{~mL}$ of the initial inoculum with $200 \mathrm{~mL}$ of the medium supplemented with $1 \% \mathrm{w} / \mathrm{v}$ of CG

Table 1. Characteristics of Glycerol

\begin{tabular}{lcccc}
\hline \multirow{2}{*}{ Glycerol types } & \multicolumn{3}{c}{ Parameters } \\
\cline { 2 - 5 } & Purity (\%wt.) & Water content (\%wt.) & NaCl (\%wt.) & Fatty acid and ester (\%wt.) \\
\hline CG & 83.3 & 11.2 & 4.8 & 0.62 \\
PG & 99.9 & 0.047 & - & 0.2 \\
\hline
\end{tabular}


and $20 \mathrm{~g} / \mathrm{L} \mathrm{MgCO}_{3}$. The mixture was fermented for $24 \mathrm{~h}$. After that, $100 \mathrm{~mL}$ of medium containing 1\%w/v of CG supplemented with $20 \mathrm{~g} / \mathrm{L} \mathrm{MgCO}_{3}$ was periodically added to the reactor every $24 \mathrm{~h}$ for $4 \mathrm{~d}$. Finally, fermentation was further proceeded for 3 $\mathrm{d}$ without adding any medium to the reactor.

\subsubsection{Semi-continuous fermentation}

This mode was studied in two processes either with or without inoculum addition during CG fermentation in CSTR. Semi-continuous fermentation with inoculum addition was started similar to batch fermentation for $72 \mathrm{~h}$. After that $240 \mathrm{~mL}$ of the fermented broth was drained while the new feed was added to the reactor every day to maintain a Hydraulic Retention Time (HRT) of 72 $\mathrm{h}$. The mixture of the new feed was consisted of $120 \mathrm{~mL}$ of inoculum and $120 \mathrm{~mL}$ of culture medium with $1 \% \mathrm{w} / \mathrm{v}$ of CG and $20 \mathrm{~g} / \mathrm{L}$ $\mathrm{MgCO}_{3}$ while $240 \mathrm{~mL}$ of the culture medium with $1 \% \mathrm{w} / \mathrm{v}$ of CG and $20 \mathrm{~g} / \mathrm{L} \mathrm{MgCO}_{3}$ was added to the fermentation mixture in the process without adding inoculum.

\subsection{Analytical Method}

Samples from all experiments were collected every $24 \mathrm{~h}$ to analyze the efficiency of succinic acid production. The samples were centrifuged at 10,000 rpm for $10 \mathrm{~min}$. The supernatant was separated and analyzed using High Performance Liquid Chromatography (CTO-10AS VP, Shimadzu, Kyoto, Japan) equipped with a Refractive Index (RI) detector RID-10A and UV-VIS Detector SPD-20A/20AV, and an Aminex HPX-87H column (Biorad, Hercules, CA) to measure succinic acid and metabolites. The mobile phase comprised $5 \mathrm{mM}$ $\mathrm{H}_{2} \mathrm{SO}_{4}$ solution at a flow rate of $0.5 \mathrm{~mL} / \mathrm{min}$ and the column was controlled at $50^{\circ} \mathrm{C}$.

\section{Results and Discussion}

\subsection{Effect of carbonate salts on bio-succinic acid fermenta- tion by $A$. succinogenes in serum bottle experiment}

This section was designed to study the effects of carbonate salts on succinic acid production in term of metabolic pathway by $A$ succinogenes using PG and CG as the carbon source in small-scale experiments. Table 2 shows succinic acid concentrations, productivities, yields, the ratio of acetic acid to glycerol (AA/GL) and the ratio of acetic acid to succinic acid (AA/SA) from batch fermentation with different carbonate salts as an additive. According to the results, the maximum succinic acid concentration obtained were 6.8 and $6.5 \mathrm{~g} / \mathrm{L}$ using PG supplemented with $40 \mathrm{~g} /{\mathrm{L} \mathrm{MgCO}_{3}}$ and CG supplemented with $20 \mathrm{~g} / \mathrm{L} \mathrm{MgCO}_{3}$, respectively. It was found that the metabolic pathway under these fermentation conditions supplemented with $\mathrm{MgCO}_{3}$ was based on the $\mathrm{C}_{4}$ pathway as suggested by the metabolite profiles. AA/SA ratio was decreased in both fermentation mixtures using either pure or crude glycerol with $\mathrm{MgCO}_{3}$. In fermentation of $\mathrm{CG}$ with $\mathrm{CaCO}_{3}$, AA/SA tended to increase during the fermentation process. Normally, glycerol degradation pathway by $A$. succinogenes is consisted of $\mathrm{C}_{3}$ and

Table 2. Summary of Succinic Acid Concentration, Yield, Productivity, AA/GL and AA/SA from PG and CG Fermentation with Different Carbonate Salts in $0.1 \mathrm{~L}$ Serum Bottles at the $96^{\text {th }} \mathrm{h}$ Fermentation

\begin{tabular}{|c|c|c|c|c|c|c|c|}
\hline Samples & Glycerol $^{\mathrm{a}}(\mathrm{g} / \mathrm{L})$ & Final $[\mathrm{SA}](\mathrm{g} / \mathrm{L})$ & Yield $^{\mathrm{b}}(\mathrm{g} / \mathrm{g})$ & Productivity $^{\mathrm{c}}$ (g SA/L.h) & $\mathrm{AA} / \mathrm{GL}^{\mathrm{d}}(\mathrm{g} / \mathrm{g})$ & AA/SA ${ }^{\mathrm{e}}(\mathrm{g} / \mathrm{g})$ & pH \\
\hline \multicolumn{8}{|l|}{$1 \%$ PG } \\
\hline no carbonate salts & $10.6 \pm(0.3)$ & $2.5 \pm(0.3)$ & $1.1 \pm(0.1)$ & $0.5 \pm(0.1)$ & 0.03 & 0.14 & 6.68 \\
\hline $20 \mathrm{~g} / \mathrm{L} \mathrm{MgCO}_{3}$ & $10.1 \pm(0.0)$ & $5.3 \pm(0.3)$ & $1.3 \pm(0.1)$ & $1.1 \pm(0.1)$ & 0.06 & 0.11 & 7.72 \\
\hline $40 \mathrm{~g} / \mathrm{L} \mathrm{MgCO}_{3}$ & $10.2 \pm(0.2)$ & $6.8 \pm(0.1)$ & $1.1 \pm(0.1)$ & $1.4 \pm(0.0)$ & 0.05 & 0.07 & 7.88 \\
\hline $60 \mathrm{~g} / \mathrm{LgCO}_{3}$ & $10.0 \pm(0.4)$ & $4.5 \pm(0.4)$ & $1.5 \pm(0.1)$ & $0.9 \pm(0.1)$ & 0.05 & 0.12 & 7.61 \\
\hline $20 \mathrm{~g} / \mathrm{L} \mathrm{CaCO}_{3}$ & $10.2 \pm(0.2)$ & $3.7 \pm(0.2)$ & $1.1 \pm(0.1)$ & $0.8 \pm(0.0)$ & 0.05 & 0.13 & 6.96 \\
\hline $40 \mathrm{~g} / \mathrm{L} \mathrm{CaCO}_{3}$ & $10.1 \pm(0.2)$ & $2.4 \pm(0.2)$ & $1.4 \pm(0.2)$ & $0.5 \pm(0.0)$ & 0.05 & 0.20 & 7.03 \\
\hline $60 \mathrm{~g} / \mathrm{L} \mathrm{CaCO}_{3}$ & $10.4 \pm(0.2)$ & $3.3 \pm(0.3)$ & $1.2 \pm(0.1)$ & $0.7 \pm(0.1)$ & 0.05 & 0.15 & 6.92 \\
\hline \multicolumn{8}{|l|}{$1 \%$ CG } \\
\hline no carbonate salts & $9.7 \pm(0.9)$ & $2.6 \pm(0.1)$ & $3.9 \pm(0.2)$ & $0.6 \pm(0.0)$ & 0.05 & 0.19 & 6.85 \\
\hline $20 \mathrm{~g} / \mathrm{L} \mathrm{MgCO}_{3}$ & $9.9 \pm(0.2)$ & $6.5 \pm(0.1)$ & $2.1 \pm(0.1)$ & $1.3 \pm(0.0)$ & 0.04 & 0.06 & 7.41 \\
\hline $40 \mathrm{~g} / \mathrm{LgCO}_{3}$ & 9. $9 \pm(0.1)$ & $6.1 \pm(0.2)$ & $1.1 \pm(0.1)$ & $1.3 \pm(0.0)$ & 0.04 & 0.06 & 7.48 \\
\hline $60 \mathrm{~g} / \mathrm{LgCO}_{3}$ & $10.5 \pm(0.3)$ & $3.0 \pm(0.1)$ & $1.2 \pm(0.1)$ & $0.6 \pm(0.0)$ & 0.04 & 0.13 & 7.66 \\
\hline $20 \mathrm{~g} / \mathrm{L} \mathrm{CaCO}_{3}$ & $10.3 \pm(0.4)$ & $1.1 \pm(0.1)$ & $1.6 \pm(0.1)$ & $0.2 \pm(0.0)$ & 0.01 & 0.11 & 7.17 \\
\hline $40 \mathrm{~g} / \mathrm{L} \mathrm{CaCO}_{3}$ & $9.7 \pm(0.2)$ & $1.1 \pm(0.1)$ & $0.8 \pm(0.1)$ & $0.2 \pm(0.0)$ & 0.04 & 0.41 & 7.21 \\
\hline $60 \mathrm{~g} / \mathrm{L} \mathrm{CaCO}_{3}$ & $10.1 \pm(0.1)$ & $0.9 \pm(0.1)$ & $0.5 \pm(0.1)$ & $0.2 \pm(0.0)$ & 0.04 & 0.45 & 7.11 \\
\hline
\end{tabular}

Note: SA: succinic acid, PG: pure glycerol, CG: crude glycerol, AA: acetic acid, GL: glycerol

${ }^{a}$ Initial glycerol concentration

b Succinic acid yield on consumed glycerol

${ }^{\mathrm{c}}$ Succinic acid volumetric production rate in g/L.h

${ }^{\mathrm{d}}$ Ratio of produced acetic acid (AA) on consumed glycerol (GL)

e $\mathrm{AA} / \mathrm{SA}$ ratio is $\mathrm{g}-\mathrm{AA} / \mathrm{g}-\mathrm{SA}$ 
$\mathrm{C}_{4}$ pathways which involve generation of different main products. Succinic acid is the main final product of $\mathrm{C}_{4}$ metabolic pathway whereas acetic acid, formic acid and ethanol are the main final products of $\mathrm{C}_{3}$ metabolic pathway. Therefore, the ratio of AA/GL and $\mathrm{AA} / \mathrm{SA}$ can suggest the internal metabolic process of the microbial cells that assimilate the dissolved $\mathrm{CO}_{2}$ from $\mathrm{MgCO}_{3}$ in dissociated form to drive succinic acid production by $A$ succinogenes.

The results showed that the reduction trend of AA/SA observed in CG fermentation was higher than that using PG in fermentation while it was increased in all cases of fermentation with $\mathrm{CaCO}_{3}$ using either PG or CG. Previous studies revealed that $\mathrm{CaCO}_{3}$ caused negative effect and resulted in the inhibition of bacterial cell growth, leading to a lower cell density in the fermentation mixture than that observed using $\mathrm{MgCO}_{3} . \mathrm{MgCO}_{3}$ is regarded as the most effective $\mathrm{CO}_{2}$ supplier and buffer agent for bio-succinic production [20-21]. Besides, $\mathrm{MgCO}_{3}$ can prevent flocculation and support dissolved $\mathrm{CO}_{2}$ more than $\mathrm{CaCO}_{3}$ [22-23]. However, the AA/GL ratio was increased in the fermentation using PG with carbonate salts compared with that without carbonate salts while this ratio was decreased for all cases using CG with carbonate salts. The results indicated that adding carbonate salts led to induction of the $\mathrm{C}_{3}$ metabolic pathway in PG. This can be explained by the buffer capability of the carbonate salts. Compared to PG, CG contained a substantial amount of long chain fatty acids such as palmitic and oleic acid and $4.8 \% \mathrm{w} / \mathrm{v} \mathrm{NaCl}$. These impurities could inhibit anaerobic fermentation by the strain. Utilization of CG by the microbial cells may also be suppressed due to high concentrations of soluble chemicals and salts in the medium. This resulted in more complex metabolic scenarios on nutrient assimilation and limits utilization of CG by the pure strain. Under the suitable $\mathrm{pH}$ condition, PG can be assimilated more efficiently than CG and passed to the glycolysis pathway. Acetic and formic acid are then produced via $\mathrm{C}_{3}$ pathway, and finally ATP is generated for driving microbial activities. Due to economic reason, CG was then used for the subsequent study on further optimization of the fermentation process.

\subsection{Effect of Operation Modes in CSTR}

The performance of $A$. succinogenes on fermentation of CG for succinic acid production was studied in 1-L CSTR fermenters. The processes were operated using different types of operation modes including batch, fed batch and semi-continuous fermentation. The process performance was compared based on

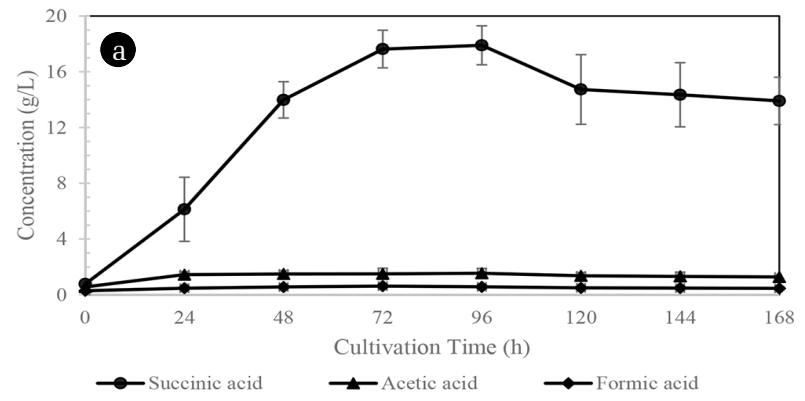

the product yield and glycerol utilization efficiency.

\subsubsection{Batch fermentation}

In the batch operation mode, the results showed that succinic acid concentration increased continuously with the maximum succinic acid concentration of $17.9 \mathrm{~g} / \mathrm{L}$ at the $96^{\text {th }} \mathrm{h}$ of fermentation. After that, it tended to decrease and stabilize until the end of batch fermentation (Fig. 1 (a)). Succinic acid concentration was correlated with glycerol concentration (Fig. 1 (b)). Glycerol concentration decreased continuously from the initial concentration of $10.2 \mathrm{~g} / \mathrm{L}$ to the $96^{\text {th }} \mathrm{h}$ fermentation where the maximum glycerol utilization of $99.9 \%$ was reached, leading to the product yield of $1.8 \mathrm{~g} / \mathrm{g}$. The results indicated that the major metabolic pathway of CG fermentation by $A$. succinogenes was the $\mathrm{C}_{4}$ pathway where succinic acid was the predominant type of end product while acetic and formic acid were minimally observed. The $\mathrm{pH}$ was decreased at the first $24^{\text {st }}$ fermentation from the initial $\mathrm{pH}$ of 7.89 to the range of 7.13-7.77 throughout the fermentation.

\subsubsection{Fed batch fermentation}

In the fed-batch operation mode, the maximum succinic acid concentration was $10.4 \mathrm{~g} / \mathrm{L}$ at the $96^{\text {th }} \mathrm{h}$ of fermentation (Fig. 2 (a)). After that, the succinic acid concentration was continuously decreased after the $120^{\text {th }} \mathrm{h}$. This corresponded with the decrease of glycerol from an initial concentration of $9.6 \mathrm{~g} / \mathrm{L}$ to $1.6 \mathrm{~g} / \mathrm{L}$ at the $96^{\text {th }} \mathrm{h}$ of fermentation. The results indicated that $A$ succinogenes could use glycerol up to $99.7 \% \mathrm{w} / \mathrm{w}$ under this operation mode (Fig. 2 (b)). This led to the final product yield of $1.3 \mathrm{~g} / \mathrm{g}$. However, the trend of acetic acid produced during the fed batch fermentation was higher than that in the batch fermentation. This implied that the $\mathrm{C}_{3}$ pathway showed an increasing role as the internal metabolic pathway of $A$. succinogenes for its growth under this condition. In addition, ATP generation via the $\mathrm{C}_{3}$ pathway was necessary for this operation mode to support the internal activity of the bacterial cells. From the initial $\mathrm{pH}$ of 7.38 , the $\mathrm{pH}$ was decreased to 6.85 at the $48^{\text {st }}$ fermentation after adding the new medium into the reactor and then varying in the range of 7.10-7.93 throughout the fermentation.

\subsubsection{Semi-continuous fermentation}

The results showed that succinic acid concentration obtained from semi-continuous operation with addition of inoculum during fermentation was continuously increased. The maximum succinic

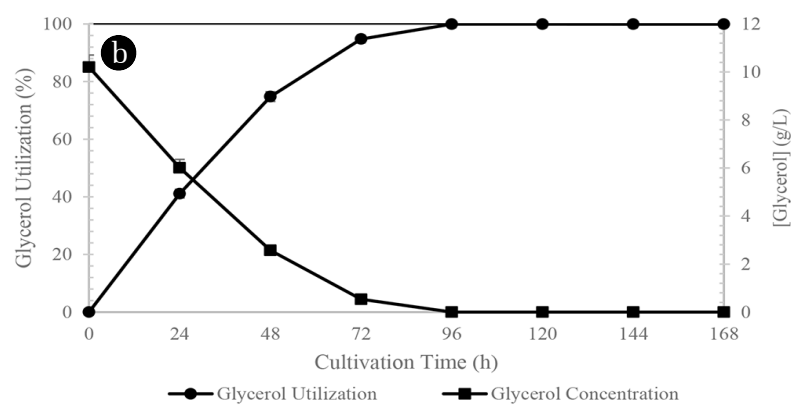

Fig. 1. Acid production and glycerol utilization during batch fermentation in 1-L CSTR. The process was operated using $1 \%$ CG and $20 \mathrm{~g} / \mathrm{L} \mathrm{MgCO}{ }_{3}$ for7d under the fixed condition at $37^{\circ} \mathrm{C}$ with mixing at $150 \mathrm{rpm}$ (a) Succinic $(\bullet)$, acetic $(\boldsymbol{\Delta})$ and formic $(\bullet)$ acid concentration; (b) glycerol utilization $(\bullet)$ and glycerol concentration (घ). 

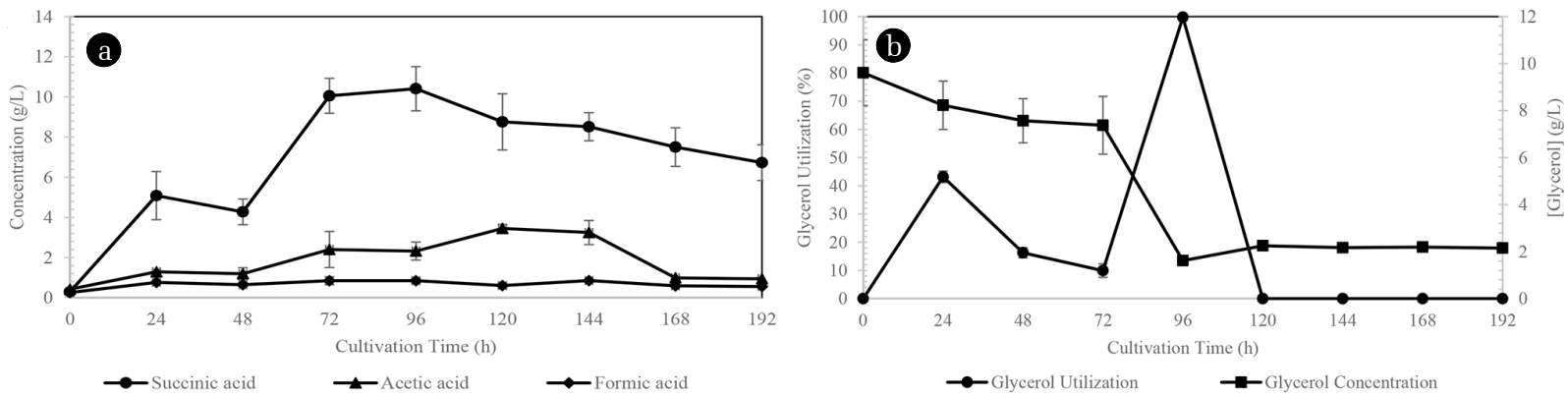

Fig. 2. Acid production and glycerol utilization during fed-batch fermentation in 1-L CSTR. The new medium containing $1 \%$ CG and $20 \mathrm{~g} / \mathrm{L} \mathrm{MgCO} 3$ wasperiodicallyaddedtothereactorevery24hoursfor4 days and further proceeded for $3 \mathrm{~d}$ without adding any medium to the reactor (a) Succinic $(\bullet)$, acetic $(\mathbf{\Lambda})$ and formic $(\bullet)$ acid concentration; (b) \%glycerol utilization $(\bullet)$ and glycerol concentration $(\boldsymbol{\bullet})$.
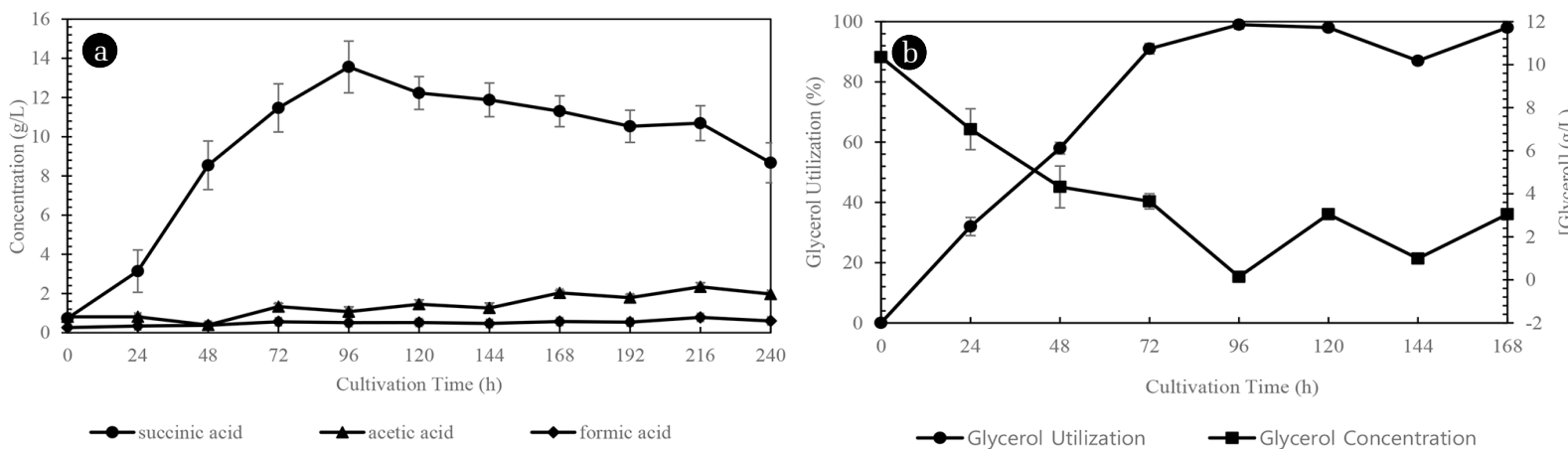

Fig. 3. Acid production and glycerol utilization during semi-continuous fermentation with inoculum addition in 1-L CSTR by keeping the HRTs of 3 days with 1:1 mixture of the medium containing 1\%CG and $20 \mathrm{~g} / \mathrm{L} \mathrm{MgCO}$ andtheinoculum.(a)Succinic $(\bullet)$, acetic $(\boldsymbol{\Delta})$ and formic $(\bullet)$ acid concentration; (b) \%glycerol utilization $(\bullet)$ and glycerol concentration (घ).
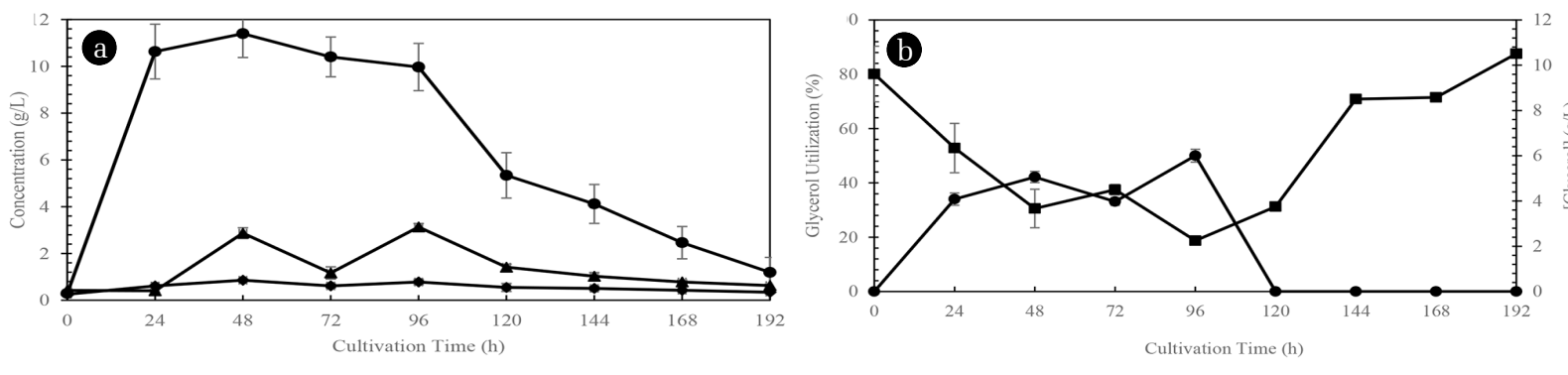

$\rightarrow$ succinic acid $\quad \longrightarrow$ acetic acid $\rightarrow$ formic acid

$\rightarrow$ Glycerol Utilization $\quad \rightarrow$ Glycerol Concentration

Fig. 4. Acid production and glycerol utilization during semi-continuous fermentation without inoculum addition in 1-L CSTR by keeping the HRTs of 3 days with addition of $1 \% \mathrm{CG}$ and $20 \mathrm{~g} / \mathrm{L} \mathrm{MgCO}_{3}$ with noinoculum addition) (a) Succinic $(\bullet)$, acetic $(\mathbf{\Delta})$ and formic $(\bullet)$ acid concentration; (b) glycerol utilization $(\bullet)$ and glycerol concentration (ロ).

acid concentration was $13.6 \mathrm{~g} / \mathrm{L}$ observed at the $96^{\text {th }} \mathrm{h}$ of fermentation. In contrast, acetic and formic acids were observed at low concentrations that remained in the range of $0.7-2.3$ g/L and $0.3-0.8$ g/L, respectively (Fig. 3 (a)). Glycerol utilization reached $96.3 \% \mathrm{w} / \mathrm{w}$ at the $96^{\text {th }} \mathrm{h}$ (Fig. 3 (b)), leading to the maximum product yield of $1.3 \mathrm{~g} / \mathrm{g}$. After adding the new feed, glycerol utilization was maintained in the range of $87.0-99.0 \% \mathrm{w} / \mathrm{w}$ until the end of the experiment $\left(240^{\text {th }} \mathrm{h}\right.$; data not shown). The $\mathrm{pH}$ showed a decreasing trend from 7.67 to 6.50 and lower than those from batch and fed batch operations.

Fig. 4 (a) and (b) showed results of CG fermentation in the semi-continuous operation without addition of inoculum during fermentation. The maximum succinic acid was $11.4 \mathrm{~g} / \mathrm{L}$ at the first $48^{\text {th }} \mathrm{h}$ of fermentation, equivalent to the product yield of 1.9 g/g. After that, succinic acid concentration was continuously decreased. Acetic and formic acid concentrations were $0.4-3.1$ g/L, and $0.3-0.9$ g/L, respectively (Fig. 4 (a)). The maximum glycerol utilization under this condition was $50.0 \%$ at the $96^{\text {th }} \mathrm{h}$ of fermentation while no further glycerol consumption was observed after this time point. Glycerol was gradually accumulated from the new feeding. The $\mathrm{pH}$ in the system tended to increase after adding the new medium and drainage the fermented broth that was in the range of 7.08-9.31. Some of the bacterial cells were lost during draining of the cultured broth from the CSTR every day to maintain 
the HRTs of $3 \mathrm{~d}$. This resulted in the lower amount of cells remained in the reactor which affected glycerol assimilation and led to accumulation of glycerol in the mixture during the $120^{\text {th }}-192^{\text {th }} \mathrm{h}$. Moreover, the bacterial cells could not be promptly proliferated and grown. Addition of the bacteria into the system during the fermentation process was thus found to directly affect the overall efficiency of the fermentation system in terms of both glycerol assimilation and succinic acid production.

\subsection{Effect of Dissolved $\mathrm{CO}_{2}$ from Initial $\mathrm{CO}_{2}$ Purging on Batch Fermentation in CSTR}

In this part, the effects of $\mathrm{CO}_{2}$ purging period on succinic acid production via the $\mathrm{C}_{4}$ pathway by $A$. succinogenes was studied by adding gaseous $\mathrm{CO}_{2}$ during batch fermentation. Co-fermentation of $\mathrm{CO}_{2}$ was reported for succinic acid production by $A$. succinogenes. Fermentation with a higher concentration of dissolved $\mathrm{CO}_{2}$ was reported to increase the ratio of succinic acid to the other metabolites, the ratio of carbon recovery, and finally the succinic acid yield [24]. According to our results, it is indicated that not only $\mathrm{MgCO}_{3}$ but also the period of initial $\mathrm{CO}_{2}$ purging to start up the fermentation led to different performance of the bacteria on both glycerol uptake and internal metabolic process via the $\mathrm{C}_{3}$ and $\mathrm{C}_{4}$ pathways. Fermentation with initial $\mathrm{CO}_{2}$ purging for $1 \mathrm{~min}$ resulted in a higher concentration of succinic acid than fermentation with initial $\mathrm{CO}_{2}$ purging for 3 and $5 \mathrm{~min}$ (Fig. 5 (a)). The results illustrated that the highest succinic acid concentration of $17.9 \mathrm{~g} / \mathrm{L}$ was achieved at the $96^{\text {th }} \mathrm{h}$ of fermentation and then decreased until the end of batch fermentation. Similarly, the trend of glycerol utilization under the condition with initial $\mathrm{CO}_{2}$ purging for $1 \mathrm{~min}$ was higher since the start of the batch process (Fig. 5 (b)). The maximum glycerol utilization reached $94.8 \%$ within $72 \mathrm{~h}$, while glycerol utilization under the condition of purging $\mathrm{CO}_{2}$ for 3 and 5 min was slower (Fig. 5 (b)). Regarding acetic and formic acid production, metabolites in the $\mathrm{C}_{3}$ pathway were higher throughout the fermentation process under the condition of purging $\mathrm{CO}_{2}$ for 3 and $5 \mathrm{~min}$ compared with the condition of purging $\mathrm{CO}_{2}$ for $1 \mathrm{~min}$ (Fig. 5 (c) and (d)). The results suggested that gaseous $\mathrm{CO}_{2}$ could be used as both co-substrates to support the $\mathrm{C}_{4}$ pathway through the reverse TCA cycle and as a main factor in growth and proliferation of the cells via the $\mathrm{C}_{3}$ pathway. In general, the $\mathrm{C}_{3}$ pathway induced not only acetic and formic acid production, but also generation of ATP to use as an energy source of the microbial cells for their internal activities. The extended purging of gaseous $\mathrm{CO}_{2}$ could result in increasing dissolved $\mathrm{CO}_{2}$ along with a high partial pressure of $\mathrm{CO}_{2}$ in the fermentation system. This result agreed with the related research of $\mathrm{Xi}$ et al. (2011) [25] which investigated the effect of different $\mathrm{CO}_{2}$ partial pressure on $\mathrm{CO}_{2}$ fixation by $A$. succinogenes. They reported that the condition with $0.1 \mathrm{MPa}$ of $\mathrm{CO}_{2}$ resulted in the maximum amount of dissolved $\mathrm{CO}_{2}$ in the broth. The maximum amount of dissolved $\mathrm{CO}_{2}\left(\mathrm{dCO}_{2}\right)$ of $22.7 \mathrm{mM}$ and dry cell weight were obtained. Additionally, gaseous $\mathrm{CO}_{2}$ can enter the cell membrane and be used as a substrate for the microbial cells. On the other hand, $\mathrm{HCO}_{3}{ }^{-}$and $\mathrm{CO}_{3}{ }^{2-}$ need ATP in the process to bind with protein and transport to bacterial cells [26]. Normally, gaseous $\mathrm{CO}_{2}$ can be used by the microbial cells under the conditions containing $\mathrm{HCO}_{3}{ }^{-}, \mathrm{CO}_{3}{ }^{2-}$ and gaseous $\mathrm{CO}_{2}$ [27]. Therefore, $\mathrm{dCO}_{2}$
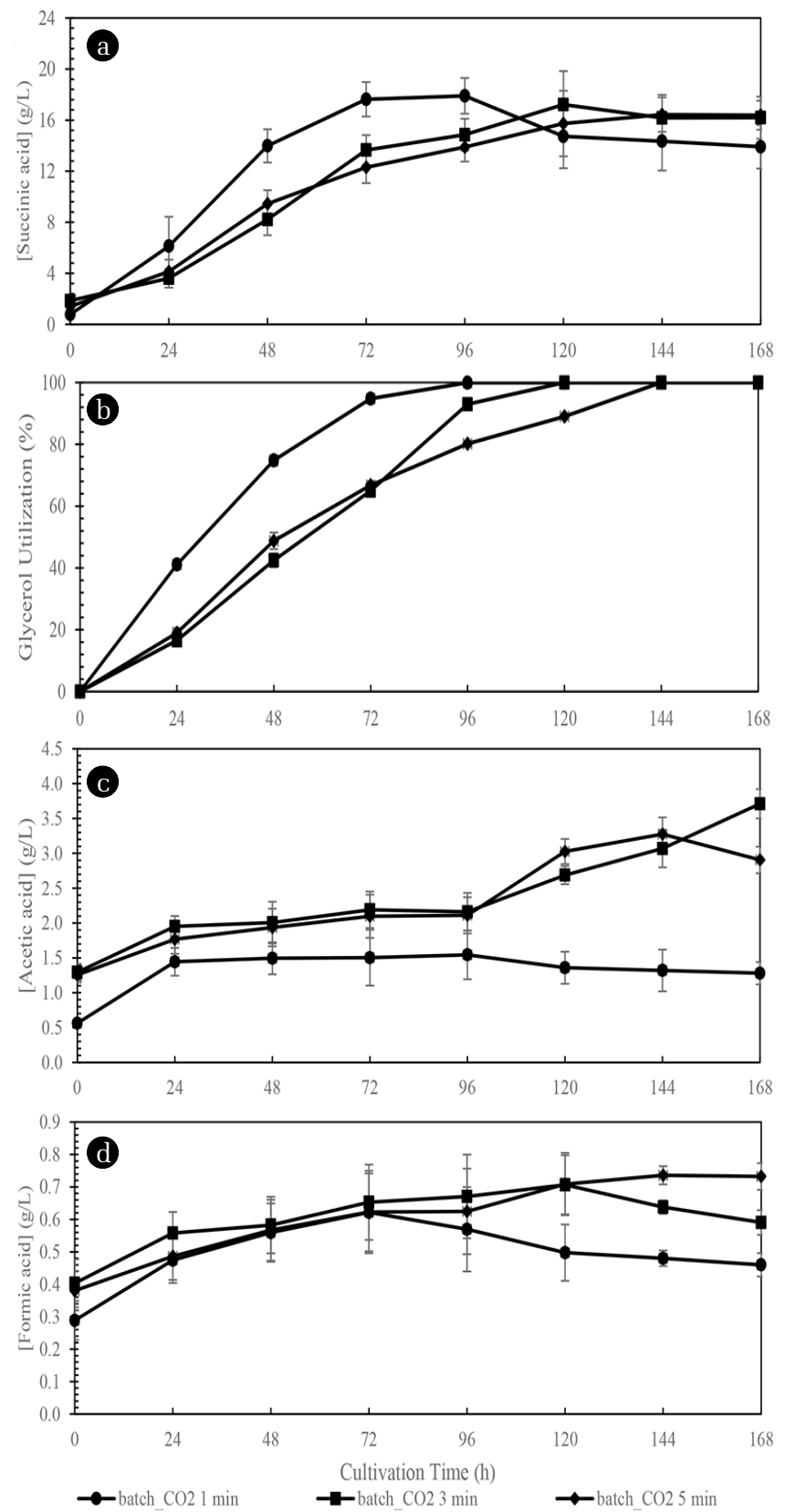

Fig. 5. Effect of $\mathrm{CO}_{2}$ purging on succinic acid production from CG in batch process. (a) Succinic acetic concentration, (b) Glycerol utilization, (c) Acetic acid concentration and (d) Formic acid concentration The symbols of $\bullet$, $\mathbf{a}$ and $\bullet$ represent batch fermentation by purging the initial $\mathrm{CO}_{2}$ for 1 , 3 and $5 \mathrm{~min}$, respectively.

in the broth was directly related to $\mathrm{CO}_{2}$ availability inside the bacterial cells. This is controlled to maintain the $\mathrm{PCO}_{2} / \mathrm{H}_{0}$ ratio according Henry's Law [28]. Moreover, $\mathrm{HCO}_{3}{ }^{-}$and $\mathrm{CO}_{3}{ }^{2-}$ could dissociate from the $\mathrm{CO}_{2}$ balance and were converted to dissolved $\mathrm{CO}_{2}$ when the rate of $\mathrm{CO}_{2}$ utilization was higher than the rate of $\mathrm{CO}_{2}$ degradation in biomass fermentation. Therefore, it is possible that the $\mathrm{HCO}_{3}^{-}$produced during the fermentation process by purging 
Table 3. Comparison of Succinic Acid Production by A. Succinogenes and Other Microbes Using Different Substrates

\begin{tabular}{|c|c|c|c|c|}
\hline Feedstock & Fermentation conditions & $\begin{array}{c}\text { Yield } \\
\text { (g SA/g substrate) }\end{array}$ & $\begin{array}{l}\text { Final }[\mathrm{SA}] \\
\quad(\mathrm{g} / \mathrm{L})\end{array}$ & References \\
\hline \multirow[b]{2}{*}{ Carob Pods } & Batch fermentation with $35 \mathrm{~g} / \mathrm{L}$ sugar, $0.05 \mathrm{vvm} \mathrm{CO} 2,37^{\circ} \mathrm{C}$ & 0.54 & 9.4 & {$[10]$} \\
\hline & $\begin{array}{l}\text { Fed batch maintaining a constant sugar concentration around } 15 \\
\mathrm{~g} / \mathrm{L} \text { in abioreactor }\end{array}$ & 0.94 & 18.6 & \\
\hline Oil palm trunk sap & $\begin{array}{l}\text { Batch fermentation in bioreactor with oil palm trunk as carbon } \\
\text { source. }\end{array}$ & 0.52 & 13.6 & [11] \\
\hline Fresh cassava root & Fed batch, $70 \mathrm{~g} / \mathrm{L}$ glucose, $40 \%$ wt $\mathrm{MgCO}_{3}, 35^{\circ} \mathrm{C}$ & 1.51 & 151.4 & {$[12]$} \\
\hline \multirow[t]{2}{*}{ Duckweed } & $\begin{array}{l}\text { Batch fermentation in } 1.3 \mathrm{~L} \text { bioreactor with corn steep liquor powder } \\
\text { as nitrogen source }\end{array}$ & 0.90 & 57.8 & {$[13]$} \\
\hline & Semi-simultaneous saccharification and fermentation & 0.80 & 72.7 & {$[14]$} \\
\hline Bagasse & Batch fermentation, $15 \mathrm{~g} / \mathrm{L}$ glucose, $0.3 \mathrm{vvm} \mathrm{CO}_{2}, 37^{\circ} \mathrm{C}$ & 0.45 & 33.6 & {$[15]$} \\
\hline Glucose & Batch fermentation, $10 \mathrm{~g} / \mathrm{L} \mathrm{MgCO}_{3}$ by Mannheimia succinoproducens & 0.55 & 9.8 & {$[16]$} \\
\hline Glycerol & $\begin{array}{l}\text { Batch fermentation with combined nitrogen sources (Corn Steep } \\
\text { Liquor: tryptone at the ratio of } 2: 1(\mathrm{w} / \mathrm{w}) \text { ) by Yarrowia lipolytica }\end{array}$ & 0.41 & 11.5 & {$[17]$} \\
\hline Glycerol & $\begin{array}{l}\text { Batch fermentation, } 10 \mathrm{~g} / \mathrm{L} \text { glycerol, } 0.04 \mathrm{vvm} \mathrm{CO}_{2}, 37^{\circ} \mathrm{C} \text { by } A \text {. } \\
\text { succinogenes }\end{array}$ & 0.85 & 12. 8 & [18] \\
\hline Crude glycerol & Batch fermentation in $1 \mathrm{~L}$ bioreactor, 1 min $\mathrm{CO}_{2}$ purge, $20 \mathrm{~g} / \mathrm{L} \mathrm{MgCO}_{3}$ & 1.75 & 17.9 & This study \\
\hline
\end{tabular}

the initial $\mathrm{CO}_{2}$ for 3 and $5 \mathrm{~min}$ and $\mathrm{CO}_{3}{ }^{2-}$ dissociated from $\mathrm{MgCO}_{3}$ could pass into the bacterial cells using ATP in the initial period. The internal reaction of metabolite flux to the $\mathrm{C}_{3}$ pathway resulted in production ATP, acetic and formic acid at the $24^{\text {th }}-96^{\text {th }}$ $\mathrm{h}$ of fermentation. This was evidently observed at the $120^{\text {th }}-168^{\text {th }}$ $\mathrm{h}$ of fermentation under the condition of $\mathrm{CO}_{2}$ purging for 3 and 5 min which was also higher than the condition with purging $\mathrm{CO}_{2}$ for $1 \mathrm{~min}$. The amount of $\mathrm{HCO}_{3}{ }^{-}$and $\mathrm{CO}_{3}{ }^{2-}$ permeated into the microbial cells and converted to dissolved $\mathrm{CO}_{2}$ could promote succinic acid production via the $\mathrm{C}_{4}$ pathway. This corresponded to glycerol utilization remained in the $96-168^{\text {th }} \mathrm{h}$ fermentation in both cases. In summary, the period of initial $\mathrm{CO}_{2}$ purging in the fermentation system affected glycerol utilization, $\mathrm{HCO}_{3}{ }^{-}$and $\mathrm{CO}_{3}{ }^{2-}$ absorption, and finally the internal metabolic pathway related to succinic production by $A$. succinogenes.

The succinic acid concentration and yield obtained in our work based on the batch fermentation in CSTR using CG as the carbon source are in the same range to those reported in previous works (Table 3). A. succinogenes was studied for succinic acid production from different renewable carbon sources, for examples, glucose, oil palm trunk sap, carob pods, bagasse, duckweed and fresh cassava roots which resulted in the final succinic acid concentration and product yield of 9.4-151.4 g/L and 0.4-1.5 g/g., respectively [10-18]. The product titer and yield obtained in our study were also comparable to those previously reported using $A$. succinogenes with glycerol as the substrate in batch fermentation which was 12.8 $\mathrm{g} / \mathrm{L}$ and $0.9 \mathrm{~g} / \mathrm{g}$ [18]. Considering the current cost of CG from local biodiesel producer (0.12-0.15 USD/L) [29] and the price of succinic acid (0.9 USD $/ \mathrm{kg}$ ) [30], there is still a margin for the developing technology for economically feasible production of succinic acid from CG. The feasibility can be further improved by enhancing performance of the microbial strains by genetic engineering techniques together with the development and optimization of bio-proc- esses with cost improved effectiveness.

\section{Conclusions}

A bioprocess for production of bio-succinic acid from CG by $A$. succinogenes was reported in this study. The batch process was found to be more efficient compared to the fed-batch and semi-continuous operations under the experimental conditions according to the product concentration and glycerol utilization. Dissolved $\mathrm{CO}_{2}$ and carbonate salts were important factors on driving the internal metabolic pathway to bio-succinic production through the $\mathrm{C}_{4}$ pathways. The flux to the $\mathrm{C}_{4}$ pathway was more obviously observed using CG compared to PG fermentation together with the preference of $\mathrm{MgCO}_{3}$ over $\mathrm{CaCO}_{3}$. The work provided a basis for process development on bio-succinic acid production from CG in industry.

\section{Acknowledgment}

Financial support for this research was granted by the Agricultural Research Development Agency (Public Organization) (Grant no. POP6005020710). The authors sincerely thank the National Center for Genetic Engineering and Biotechnology (BIOTEC) for providing laboratory support.

\section{Author Contributions}

S.K. (Assistant Professor) designed the study, conducted the experiments, analysed and discussed the results and wrote the manuscript. V.C. (Ph.D.) supervised the project and proved the manuscript. C.S. 
(Assistant Professor) discussed the results and contributed to the final manuscript. N.P. (Assistant Professor) proved the manuscript.

\section{References}

1. Department of Alternative Energy Development and Efficiency. Alternative Energy Development Plan: AEDP 2015-2036 [Internet]. [cited 14 May 2020]. Available from:https://www. dede.go.th/download/files/AEDP2015 Final version.pdf.

2. Quispe CAG, Coronado CJR , Carvalho JA. Glycerol: Production, consumption, prices, characterization and new trends in combustion. Renew. Sust. Energ. Rev. 2013;27:475-493.

3. International Energy Agency. Biofuels for transport an international perspective. Paris: Chirat; 2004.

4. Luo X, Ge X, Cui S, Li Y. Value-added processing of crude glycerol into chemicals and polymers. Bioresour. Technol. 2016;215:144-154.

5. Carvalho M, Matos M, Roca C, Reis MAM. Succinic acid production from glycerol by Actinobacillus succinogenes using dimethylsulfoxide as electron acceptor. N. Biotechnol. 2014;31(1): 133-139.

6. Vlysidis A, Binns M, Webb C, Theodoropoulos C. Glycerol utilisation for the production of chemicals: Conversion to succinic acid, a combined experimental and computational study. Biochem. Eng. J. 2011;58-59:1-11.

7. Pinazo JM, Domine ME, Parvulescu V, Petru F. Sustainability metrics for succinic acid production: A comparison between biomass-based and petrochemical routes. Catal Today. 2015; 239:17-24.

8. Zeikus JG, Jain MK, Elankovan P. Biotechnology of succinic acid production and markets for derived industrial products. Appl. Microbiol. Biotechnol. 1999;51:545-552.

9. Saxena RK, Saran S, Isar J, Kaushik R. Production and Applications of Succinic Acid. Current Developments in Biotechnology and Bioengineering. 1st ed. Elsevier; 2017. p.601-630.

10. Carvalho M, Roca C, Reis MAM. Improving succinic acid production by Actinobacillus succinogenes from raw industrial carob pods. Bioresour. Technol. 2016;218:490-497.

11. Burhari NA, Loh SK, Nasrin AB, et al. Compatibility of utilising nitrogen-rich oil palm trunk sap for succinic acid fermentation by Actinobacillus succinogenes 130Z. Bioresour. Technol. 2019;293:1-8.

12. Thuy NTH, Kongkeaw A, Flood A, Boontawan A. Fermentation and crystallization of succinic acid from Actinobacillus succinogenes ATCC55618 using fresh cassava root as the main substrate. Bioresour. Technol. 2017;233:342-352.

13. Shen N, Wang Q, Zhu J, et al. Succinic acid production from duckweed (Landoltia punctate) hydrolysate by batch fermentation of Actinobacillus succinogenes GXAS137. Bioresour. Technol. 2016;211:307-312.

14. Shen N, Zhang H, Qin Y et al. Efficient production of succinic acid from duckweed (Landoltia punctate) hydrolysate by Actinobacillus succinogenes GXAS137. Bioresour. Technol. 2018;250:35-42.

15. Corona-Gonzalez RI, Varela-Almanza KM, Arriola-Guevara E, et al. Bagasse hydrolyzates from Agave tequilana as substrates for succinic acid production by Actinobacillus succinogenes in batch and repeated batch reactor. Bioresour. Technol. 2016;205:15-23.

16. Song H, Lee J, Choi S, et al. Effects of dissolved $\mathrm{CO}_{2}$ levels on the growth of Mannheimia succiniciproducens and succinic acid production. Biotechnol. Bioeng. 2007;98(6):1296-1304.

17. Li C, Gao S, Wang $\mathrm{H}$ et al. Succinic acid production using a glycerol-based medium by an engineered strain of Yarrowia lipolytica: Statistical optimization and preliminary economic feasibility study. Biochem. Eng. J. 2018;137:305-313.

18. Vlysidis A, Binns M, Webb C, Theodoropoulos C. Glycerol utilisation for the production of chemicals: Conversion to succinic acid, a combined experimental and computational study. Biochem. Eng. J. 2011;58-59:1-11.

19. Carvalho M, Matos M, Roca C, Reis MAM. Succinic acid production from glycerol by Actinobacillus succinogenes using dimethylsulfoxide as electron acceptor. New Biotechnol. 2014;31:133-139.

20. Dessie W, Xin F, Zhang W et al. Opportunities, challenges, and future perspectives of succinic acid production by Actinobacillus succinogenes. Appl Microbiol Biotechnol. 2018; 102(23):9893-9910.

21. Liu Y P, Sun ZH, Ni Y, Dong JJ, Wei P. Strategies of $\mathrm{pH}$ control and glucose-fed batch fermentation for production of succinic acid by Actinobacillus succinogenes CGMCC1593. J Chem Technol Biotechnol. 2008;88(5):722-729

22. Liu P, Zheng P, Sun ZH, Ni Y, Dong JJ, Zhu LL. Economical succinic acid production from cane molasses by Actinobacillus succinogenes. Bioresour Biotechnol. 2008;99:1736-1742.

23. Song H, Lee JW, Choi S, You JK, Hong WH, Lee SY. Effects of dissolved CO2 levels on the growth of Mannheimia succiniciproducens and succinic acid production. Biotechnol Bioeng. 2007;98(6):1296-1304.

24. Zou W, Zhu LW, Li HM, Tang YJ. Significance of $\mathrm{CO}_{2}$ donor on the production of succinic acid by Actinobacillus succinogenes ATCC 55618. Microb Cell Fact. 2011;10(1):87.

25. Xi YL, Chen KQ, Li J. et al. Optimization of culture conditions in $\mathrm{CO}_{2}$ fixation for succinic acid production using Actinobacillus succinogenes. J Ind Microbiol Biotechnol. 2011;38(9):1605-1612.

26. Zhang K, Kurano N, Miyachi S. Optimized aeration by carbon dioxide gas for microalgal production and mass transfer characterization in a vertical flat-plate photobioreactor. Bioproc. Biosyst. Eng. 2002;25(2):97-101.

27. Lu S, Eiteman MA, Altman E. Effect of $\mathrm{CO}_{2}$ on succinate production in dual-phase Escherichia coli fermentations. J Biotechnol. 2009;143(3):213-223.

28. Baez A, Flores N, Bolivar F, Ramirez OT. Metabolic and transcriptional response of recombinant Escherichia coli to elevated dissolved carbon dioxide concentrations. Biotechnol. Bioeng. 2009;104:102-110.

29. Nomanbhay S, Hussein R, Ong MY. Sustainability of biodiesel production in Malaysia by production of bio-oil from crude glycerol using microwave pyrolysis: review. Green Chem Lett Rev. 2018;11(2):135-157.

30. Ghayur A, Verheyen TV, Meuleman E. Techno-economic analysis of succinic acid biorefinery coproducing acetic acid and dimethyl ether. J Clean Prod. 2019;230:1165-1175. 